\title{
THE EFFECTIVENESS OF Q AND A METHOD ON CRITICAL THINKING OF JUNIOR HIGH SCHOOL FEMALE STUDENTS
}

\author{
Esmaeil Sadipour \\ Department of Psychology, AllamehTabataba'i University, Iran \\ MahdiyeHallajian \\ Department of Psychology, AllamehTabataba'i University, Iran \\ Hallajian67@gmail.com
}

\begin{abstract}
The main idea of this research was the study of educational effect of $\mathrm{Q} \& \mathrm{~A}$ method on critical thinking of first grade female students. This was an experimental study in which multiple group patterns with pretest and posttest with control groupwas used. The population of this study consisted of the all first grade female high school students of a governmental school in area 2 of Tehran city. 1 high school was randomly selected between 35 high schools. This high school (Hoda) had 6 first grade classes and 195 students. Watson Glaser critical thinking questionnaire (1980) was performed on 195 students. 45 students who had 1 standard deviation below the average score were randomly divided into experimental and control groups. The results showed that Q \& A method was effective on critical thinking of first grade high school students. In order to increase critical thinking of first grade high school students, teachers can use Q \& A method.
\end{abstract}

Keywords: question and answer method, critical thinking, students, and education.

\section{Q ETKINLİĞí VE GENÇ LISSESİ KIZ ÖĞRENCILERİN ELEŞTİREL DÜȘÜNME ÜZERINE BİR YÖNTEM}

ÖZ

$\mathrm{Bu}$ araştırmanın ana fikri $\mathrm{Q} \&$ birinci sınıf kız öğrencilerin eleştirel düşünme üzerine bir yöntemin eğitim etkisi çalışmadır. Bu kontrol grupları ile ön test ve son testte birden fazla grup desenleri kullanılan hangi deneysel bir çalışma oldu. Bu çalışmanın evrenini Tahran şehir alanında 2 bir devlet okulunun tüm birinci sınıf kız lise öğrencisi oluşturmuştur. 1 lise rastgele 35 liseler arasındaki seçildi. $\mathrm{Bu}$ lise (Hoda) 6 birinci sınıf dersleri ve 195 öğrenci vardı. Watson Glaser eleştirel düşünme anket (1980) 195 öğrenci üzerinde gerçekleştirildi. ortalama puanı altında 1 standart sapma vardı 45 öğrenci rastgele deney ve kontrol gruba ayrıldı.Sonuçlar, Q gösterdi \& bir yöntem birinci sınıf lise öğrencilerinin eleştirel düşünme üzerinde etkili oldu. Birinci kalite lise öğrencilerinin eleştirel düşünme artırmak amacıyla, öğretmenler Q \& A yöntemi kullanabilirsiniz.

Anahtar kelimeler: soru-cevap yöntemi, eleştirel düşünme, ögrrenciler ve eğitim

\section{INTRODUCTION}

I do not think it can be found even in one training system around the world in which one of the main aims of education not be"teaching thinking to students". But is it really all schools teach students the ways of thinking? Development of thinking skills has been always a complex issue in education, but today has taken a critical situation,because the output data of culture of people critical thinking has exceeded about itsinformation.Also, the constant changes and growing complexity of life, the amazing development of industry, progressiveand rapid procedure of human information, unprecedented population increase, tensions and conflict between different intellectual values requires the greatest efforts in the development of the students' thinking to be done.Schimanskiand Kyle (1990) stated that: "The true expression of success of an education system is not how the students 
have been successful in the school evaluation. The real measure of success of an education system is that the output of the system that are the citizens, how think, what questions they ask, what values they respect, what attitudes and beliefs they ponder about and how much their views and beliefs are and critical and analytical. So if we want to have thoughtful, creative and critical citizens, we need to teach them thinking (Faghihi, 2010).

According to the studies which were conducted during the $70 \mathrm{~s}$ and $80 \mathrm{~s}$, researchers were alarmed at the lack of emphasis of schools and universities on thinking. They stated memorizing facts, rote exercises, heavy assignments and quiet class are the main task of schools and traditional universities that prevents research, production, science, rationality and high-level thinking. In the scientific and educational centers educators and researchers usually are the main criteria of goodness and badness. They say their students to do their jobs well and good. In this case there is no thinking and learning becomessuperficial and rote. Students taking notes from teacher says his/her statement is proof, through this type of training students would bedependent to the teacher and their intellectual independence can be prevented.In this condition they rely on others even in adulthoodanddo not have the necessary intellectual standards (Nasrabadi, 2015). According to many philosophers, psychologists and educators, strengthening scientific and critical thinking need no justification because the considerationthinking as a goal in the education process itself is a proof of this. Certainly the position of any system depends on the ability of individuals to analysis of issues and thoughtful decision-making.

Ennis Lipmanand Paul (1989) believe that education of thoughtful people should be the first goal of education. According to Paul the end product of education should be a prober mind.

Seeger Erinberk(1995), who has designed several programs to thinking skills, to teach critical thinking regardingneeds and individual and social interests, emphasis on rationality.He believes that when students graduate from high school should be able to intelligently follow scientific and ethical factors and the community hastherighttheseexpectationsfrom its members. He suggests that these products that are accessible only in the light of students' thinkingshould be the basis for planning all lessons, becausethe main porpuse of education is transitioning students from a self-centered world based on limited personal experience and tangible or imposed facts toa territory of more abstract and richworld which involves multiple and diverse values, insights and facts.

Unfortunately, despite the existence of various theories about the necessity to nurture students' critical thinking, yet there is a huge gap between theory and practice in this field and it is desirable that the appropriate teaching methods to increase the skill are used, one of these methods is a Q and Amethod. Question and answer teaching method or Socratic dialectic is a method by which teachers encourage pupils to think about a new concept or expression a thought. In this method, the student tries with mental efforts move from the known to the unknown.Itis also known asSocraticmethod. Socrates believed that knowledge is in the nature of people and it is sufficient that the teacher provide the background and help the pupil to reach the desired knowledge. Socrates in discussions with studentswas not firstly consideringthe transmission of information or answer toquestionsbutthrough successive questionswasimposingpeople to think and guide them step by step to discover true answer (Sha'bani, 2008: 264-265).

In the question and answer method, the teacherin absorbing student's attention to the new course or subject and teach it, does not address directly the expression, but also with planned questions put student's mental activity on the path of new concepts and contents and guide it to themselves to explore new concepts. This procedure for reviewingthelessonsthat already havebeenlearnedor evaluating the student's perception of lesson concept and to foster their ability to think and reason is very effective.

This method is based on three principles:

1. Questions or issues that arouse students' curiosity and make them to mental effort. 
2. Planning successive questions for continuity of mental activity.

3. The conduction of mental effort to conscious discovery of issue so that lead to creative thinking and knowledge.

The aim ofQ and A methodis identify and stimulate thinking, abilities and the interests, strengthen the power of reasoning, evaluating and judging, using the experiences and knowledge of the past and create confidence in the student (Sha'bani, 2008: 264-265).

Some researches in this area are following:

Research conducted by Dam \&Volman (2004), entitled "Critical thinking as a citizen competence: teaching strategies", discussed two issues. Firstly: The educational strategies that promote critical thinking in students including: focus on the development of epistemological beliefs of students, promoting active learning, problem-based curriculum, stimulate interaction between students, learning based on real life situations. The research failed to prove the effectiveness of programs, especially for the promotion of critical thinking. The second part of this article offered recommendations about training framework for critical thinking from a perspective of social constructionism.Learningthecritical thinking is imagined asqualificationforcriticalparticipation in the communities where individualsaremembers of them.If education is beyond the critical participation in society some opportunities should be provided in classroom and school for critical observation, imitation and practice and feedback based on it.

A research was performed by Marin and Halpern (2011) to develop critical thinking in youth. Research findings show that explicit teaching is an effective way to teach critical thinking skills for high school students.

EskandarFathi (2013) conducted a study entitled "the effectiveness of strategic teaching of thinking on critical thinking of students. The results showed that thinking training had a significant effect on critical thinking. Critical thinking can be increased through direct teaching of thinking in the classroom and students engagement in discussions and class activities and involving them in the process of thinking.

Another study was performed by Kamran Ganji (2013)entitled"the effectiveness teaching of questioning skills to teachers on secondary students critical thinking. Results showed that both groups of students in terms of age, GPA, IQ and critical thinking its subscales were identical according to pre-test scores. Analysis of covariance showed that training questioning skills students has increased 12 percent critical thinking in the teachers. In five subscales of critical thinking, analysis $9 \%$, assessment $12 \%$, deduction $4 \%$, deductive reasoning $6 \%$, inductive reasoning $5 \%$ were increased. The mean difference between overall score of critical thinking skills and five subscales of it in humanities and electrotechnicalstudentswas not significant.

A study entitled "planning learning environments framework"thatpromote responsibility and critical thinking of learners in Thailand by Hongsuneeuarattanaraksaand colleagues (2012) was performed. The results showed that the model proposed in this study include these factors: problem-focused, resource center, the center of the partnership, the scaffolding woman, center for cognitive tools, management, accountability center, center for Critical thinking and related items.

Given the importance of thinking skills for students in today's world (Dam and Veloman, 2004 and Mangena\&Chabeli, 2005) and low levels of critical thinking in students (quoted by Norris, 1983, Meyerz, 1996, Babamohamadi and Khalili2004, Bahmani, et al., 2005) and the role of the teacher (Glen, 1995, Zohar, 1999, Maggi, 2006), educational environment (Ozkan, 2010; Macpherson \&Stanovich,2007) and teaching methods (papillae, 2011; Kasmurie, kitot, Ahman\&Seman, 2010; Angeli\&Valanides, 2009; Maskey, 2008; Yang, 2007) in the development of critical thinking, the effect of explicit and enlightened teaching on critical thinking (Marin and Halpern, 2011), the effectiveness of teaching critical thinking strategies on this skill (EskandarFathi, 2013), the effect of 
questioning skills training to teachers on critical thinking of students (Ganji, 2013), it is hypothesized that teaching Q and Amethod is effective on critical thinking ofjunior high school girl students.

\section{METHOD}

This research is applied and experimental (pre-test and post-test design)withcontrol group. In this study, questions and answers teaching methodis considered as experimental variable and critical thinking as dependent variable.

\section{POPULATION, SAMPLE AND SAMPLING}

The population consisted of all girl students of public high school in first grade in the second district of Tehran. This means a high school was randomly selected from 35 female high schools. This school (HUDA) had 6 first grade classes and 195 students. Watson-Glaser Critical Thinking Inventory (1980) was performed on 195 people. The 45 students who had a lower standard deviation from the mean score were randomly divided into control and experimental groups.

\section{RESEARCH TOOLS}

The tools used in this study are as follows:

\section{Watson-Glaser Critical Thinking Questionnaire (Form A)}

Watson-Glaser questionnaire (1980) contains 80 questions in five parts of deduction, recognize assumptions, inference, interpret and evaluate the reasons. The overall score of test is 80 and the highest score for each subject in each section is 16.Scores in the inferencesectionthrough right and wrong statements, in identifying assumptions by the presence or absence of defaultsin mentioned or non-mentioned statements, in deduction through extracted or not extracted results of situations, in interpretationby specifying extracted and not extracted interpretations of history, and finally, in the appraisal of the reasons by diagnosing the cause of the strong and weak reasons are obtained. In other words, in the test a score is awarded for each correct answer to test questionsand the total true answers to test questions is considered as total score of it(maximum of 80). Each of the subjects based on earned total points can be categorized asweak(less than 54), medium (59-54) and strong (80-60) in the terms of critical thinking ability. In the categorizing scores on each section for weak class score of 10 andlower,formiddle class 11 and for strong class 12-16 were considered.The required time to respond to test questions is 60 minutes. The test after translated into Persian and editing, were studied to coordinate and comparison of it with cultural and social factors. In a study conducted by IslamiandMoarefi (2010) based on a previous pilot study, narrative, validity of critical thinking testwas determined through a paired $t$ test $(t-0.4)$. The reliability of the questionnaire has been obtained 0/70 with Cronbach's alpha coefficient by JafarAbadi and Abdul (2010).

Performance methods: After sampling from the population and randomly divided into two groups of 45 subjects (23 patients) and control group $(\mathrm{n}=22)$ using Watson-Glaser critical thinking questionnaire pre-test was performed for both groups. In the experimental group, 8 sessions, twice weekly sessions (each session 1 hour) was performed to educate and answer questions. After completing the course of training, post-test was performed for both groups. Finally, the collected data were analyzed using multivariate analysis of variance.

\section{RESULTS}

Table 1The results of significance tests of multivariate analysis of variance (MANOVA) of critical thinking in students in the experimental and control groups

\begin{tabular}{|c|c|c|c|c|c|c|}
\hline eta square & $\mathrm{P}$ & d.ferror & d.fhypothesis & $\mathrm{F}$ & amount & Test name \\
\hline $0 / 785$ & $<0 / 000$ & 100 & 10 & $8 / 16$ & $0 / 926$ & اثرييلايي \\
\hline $0 / 785$ & $<0 / 000$ & 98 & 10 & $9 / 66$ & $0 / 254$ & لامبداو يلكز \\
\hline $0 / 785$ & $<0 / 000$ & 96 & 10 & $10 / 73$ & $2 / 54$ & اثر هتلينگ \\
\hline $0 / 785$ & $<0 / 000$ & 50 & 10 & $18 / 55$ & $1 / 85$ & largest \\
\hline
\end{tabular}




\section{\begin{tabular}{|l|l|l|l|l|l|}
\hline & & & & error
\end{tabular}}

As it can be seen in Table 1, the significant level of all tests, authorize the usability of multivariate analysis of variance test (MANOVA). The results show that between groups of studentsthere is a significant difference at least in one of the dependent variables. Theeta squares (which actually is the square of the correlation coefficient between the dependent variables and group membership) shows that the difference between the two groups with regard to critical thinking variablestotally is significantandthe difference is about $59 \%$ of variance relatedto the difference between the two groups in interactive effect of dependent variables.

Table 2 Results of multivariate analysis of variance (MANOVA) of critical thinking in students in the experimental and control groups

\begin{tabular}{|l|l|l|l|l|l}
\hline $\mathrm{P}$ & $\mathrm{F}$ & $\mathrm{Ms}$ & $\mathrm{Df}$ & ss & $\begin{array}{l}\text { dependent } \\
\text { variable }\end{array}$ \\
\hline $0 / 001$ & $10 / 47$ & $652 / 522$ & 2 & $635 / 121$ & Inference \\
\hline $0 / 001$ & $11 / 34$ & $289 / 226$ & 2 & $324 / 86$ & $\begin{array}{l}\text { Review } \\
\text { assumption }\end{array}$ \\
\hline $0 / 001$ & $15 / 85$ & $390 / 295$ & 2 & $821 / 502$ & deduction \\
\hline $0 / 001$ & $13 / 23$ & $537 / 429$ & 2 & $1025 / 652$ & Interpretation \\
\hline $0 / 001$ & $18 / 59$ & $98 / 052$ & 2 & $175 / 151$ & $\begin{array}{l}\text { Credential } \\
\text { Assessment }\end{array}$ \\
\hline
\end{tabular}

As Table 2 shows students who trained with the Q and Amethodcompared the control group that did not receive such training in all subscales of critical thinking, including review of assumptions, inferences, interpretation, evaluation the evidences, have obtained significantly higher scores.

Table 3 Comparison of mean difference of scores of responsibility and critical thinking in students of experimental and control groups by Tukey test

\begin{tabular}{|c|c|c|c|c|}
\hline \multicolumn{2}{|l|}{$\mathrm{X} \pm \mathrm{SD}$} & \multirow{3}{*}{$\begin{array}{l}\text { Group } \\
\begin{array}{l}1-\quad \text { question and } \\
\text { answer }\end{array}\end{array}$} & \multicolumn{2}{|c|}{ dependent variable } \\
\hline $7 / 2 \pm 2 / 3$ & pre & & deduction & Critical \\
\hline $13 / 6 \pm 4 / 6$ & post & & & \\
\hline $6 / 3 \pm 3 / 3$ & pre & \multirow{2}{*}{ 2-control } & & \\
\hline $7 / 1 \pm 3 / 6$ & post & & & \\
\hline $6 / 9 \pm 3 / 1$ & pre & \multirow{2}{*}{$\begin{array}{l}\text { 1- question and } \\
\text { answer }\end{array}$} & \multirow{4}{*}{$\begin{array}{l}\text { Review } \\
\text { assumption }\end{array}$} & \\
\hline $14 / 1 \pm 4 / 8$ & post & & & \\
\hline $7 / 3 \pm 4 / 2$ & pre & \multirow{2}{*}{ 2-control } & & \\
\hline $8 / 1 \pm 4 / 6$ & post & & & \\
\hline $6 / 4 \pm 3 / 6$ & pre & \multirow{2}{*}{$\begin{array}{l}\text { 1- question and } \\
\text { answer }\end{array}$} & \multirow[t]{4}{*}{ Inference } & \\
\hline $13 / 9 \pm 4 / 9$ & post & & & \\
\hline $6 / 5 \pm 4 / 2$ & pre & \multirow{2}{*}{ 2-control } & & \\
\hline $5 / 9 \pm 3 / 8$ & post & & & \\
\hline $6 / 8 \pm 3 / 2$ & pre & \multirow{2}{*}{$\begin{array}{l}\text { 1- question and } \\
\text { answer }\end{array}$} & \multirow[t]{4}{*}{ Interpretation } & \\
\hline $14 / 3 \pm 4 / 7$ & post & & & \\
\hline $6 / 5 \pm 3 / 3$ & pre & \multirow{2}{*}{ 2-control } & & \\
\hline $4 / 5 \pm 6 / 4$ & post & & & \\
\hline $8 \pm 2 / 9$ & pre & \multirow{2}{*}{$\begin{array}{l}1-\text { question and } \\
\text { answer }\end{array}$} & \multirow{2}{*}{$\begin{array}{l}\text { Evaluation } \\
\text { theevidences }\end{array}$} & \\
\hline $15 / 2 \pm 4 / 6$ & post & & & \\
\hline
\end{tabular}




\begin{tabular}{|l|l|l|l|l}
\hline $6 / 5 \pm 3 / 1$ & pre & 2-control & & \\
\hline $7 / 5 \pm 4 / 2$ & post & - & & \\
\hline
\end{tabular}

Tukey's post hoc test showed that questions and answers teaching method has affectedequallyon all the components of critical thinking including the inference, , review assumption, interpretation and evaluation the evidences and there is no statistically significant difference between them.

\section{DISCUSSION AND CONCLUSION}

Today, in the information age thinking skills are considered as a determining element, and people need it to control the pace of change in the world. Many educators believe that proprietary knowledge couldn't be important to tomorrow work and citizens should have the ability to learn and understand the concept of new information.Different studies that have been conducted in various countries including in Iran, indicatewhen active teaching methods are used in the class, students' critical thinking is increased (See, for example Papil, 2011; Kasmouri, Kitut, Ahmad and Saman, 2010; Angelli and Valanydz, 2009; Maski, 2008; Young, 2007; Ganji et al., 2013).

The findings of this study have shown that planning question in the lesson course has a significant effect on critical thinking of students.

In relation to the finding that groups trained by questioning in mean score of critical thinking have outperformed the control groupit could be explained in a training environment with traditional teaching methods such as lecture course materials are provided, the main activity is the responsibility of the class teacher and the teacher actively provide organized information and knowledge and plans to transfer them to students mind while thestudents are just passive observer and must rely only on what the teacher provides and maintain this information and memorize in evaluation time and respond, without the chance to practice high-level thought processes such as critical thinking.

This will be an obstacle for development of critical thinking skills. According to Vigotsky (1981, quoted by Amyrteymori et al., 2014) monologue in class leaveno place to develop critical thinking. The product of such class would be only some consumers with no opinion. According to Foley and Asmylansky "question and answer is the main element of students' thinking. So that the growth of students' thinking can be seen in the light of nurturing their questioning spirit and thus little questioning makes thinking off"(Brown and Reg, Translated by FazaeliHashemi to Persian,1999).

The results of testing of this hypothesis correspond with the results of research conducted by Papil, 2011; Kasmory, Kitut, Ahmad and Saman, 2010; Maski, 2008, and Young, 2007 that have shown active teaching methods compared with traditional methods improve critical thinking among students.

The results of this study approve the findings of a research conducted by the Dam and Wolman (2004) in terms ofcreating opportunities in the class and school for observation,imitation and critical practice and the feedback based on it.Also in line with research of Halpern and Marin (2011) entitled pedagogy to develop critical thinking in adolescents, $\mathrm{Q}$ and Amethodis an explicit method to teach critical thinking skills to high school students. Confirmingtheresearch of EskandarFathi (2013) and Kamran Ganji (2013), teaching thinking by engaging the students in the classroom and usingquestioning skills significantly effect on critical thinking increase.

In the explanation ofthe obtained results it should be noted that the basis of Q and Amethodor Socratic method is questioning and with these questions, Socrates was motivating learners to think and shake the foundations of false ideas and knowledge so that the desired result was achieved. This method, known as Socratic method of questioning is made by Socrates was considered as a way to teach critical thinking (Nasrabadi andNorouzi, 2005).

This research had no limits beyond low level of research culture and individual's cooperation and hardnessofexperimental research. As the results show the method of questions and answers enhances the student's critical thinking, it is recommended teachers, educators and parents advised use these 
methods. Also it is suggested current research is conducted in male schools with more time and on students of other grades.

\section{REFRENCES}

Babamohamadi, Hassan and Khalil Hussein. (2004). Critical thinking skills of nurse students of Medical Sciences university of Semnan. Iranian Journal of Medical Education, 4 (12): 31-23. Teymory, Amir., MH, Moradi., R. and Rasouli, Behnam. (2014). The effectiveness of E5instructional design model on critical thinking of Students in Educational Psychology. Media Journal, 5 (2): 72-61 Faghihi, Fatemeh. (2010). Curriculum reform: Nurturing intellectual skills. Journal of Education, Vol. 15, No. 59.

Ganji, Kamran. Yaghobi, Abolghasem.,Lotfali, Reza (2013). The effectiveness of questioning skills training to teachers on critical thinking of secondary students. Journal of Educational Psychology. Volume 9, Issue 27, pp. 25-1.

Shabani, H. (2008). Educational skills, Tehran, Samt publication.

Fathiazar, Eskandar and Adib, Yousef and Hashemi, T. and BadriGargari, Rahim and Gharibi, H. (2013). The effectiveness of teaching strategic thinking on critical thinking of students. New Psychological research journal (Psychology of the University of Tabriz).

Myers, Chat. (1995). Teaching critical thinking. Translated in Persian by KhudayarAbeli. Tehran: Samt publication.

Nasr Abadi, Ali and Norouzi, RezaAli (2015). Teaching critical thinking in schools and its role in the development of knowledge, creation of knowledge and theory development. Publication of Namayeh.

Angeli, Ch., \&Valanides, N. (2009). Instructional effects on critical thinking: Performance on illdefined issues, Learning and Instruction, 19: 322-334.

Dam, Green ten and Volman, Monique (2004). Critical thinking as a citizenship competence: teaching strategies. Learning and Instruction journal, volume14, Issue 4, Page 359-379.

Ennis, S, R (1962). A concept of critical thinking curriculum, Alexandra, VA, Association for supervision and curriculum development, pp. 46-54.

Glen, S. (1995). Developing critical thinking in higher education .Nurse education today. 15(30), pp 170- 178.

King, A. (1995). Designing the instructional process to enhance critical thinking across the curriculum. Teaching of Psychology 22 (1), 13-17.

Macpherson, R., \&Stanovich, K. (2007). Cognitive ability, thinking dispositions, and instructional set as predictors critical thinking, Learning and Individual Differences, 17: 115- 127.

Mangena, A., \&Chabeli, M. (2005). Strategies to overcome obstacles in the facilitation of critical thinking in nursing education. Nurse Education Today, 25, pp. 291- 295.

Marin, lisa M and Halpern, Diane F (2011). Pedagogy for developing critical thinking in adolescents. Thinking Skills And Creativity. Volume 6,page: 1-13.

Maskey, C. (2008). The coordination of clinical and didactic learning experiences to improve criticalthinking skills and academic performance, Teaching and Learning in Nursing, 3: 11- 15.

Myrick, F., \&Yonge, O. (2002). Preceptor questioning and student critical thinking. Journal of Professional Learning 18 (3), 176-181.

Norris, S.D. (1983). Synthesis of Research on Critical Thinking. Educational Leadership, 42 (4), pp 40-45.

Özkan, I. (2010). A path to critical thinking, Procedia Social and Behavioral Sciences, 3: 210-212.

Uarattanaraksa, Hongsunee\&ChaijareonSumalee\&Kanjug, Issara(2012). Designing Framework Of The Learning Environments Enhancing The Learner's Critical Thinking And Responsibility Model in Thailand. Procedia- Social and Behavioral Sciences Journal, volume 46, page 3375-3379.

Yang, Sh. Ch. (2007). E-critical/thematic doing history project: Integrating the critical thinking approach with computer-mediated history learning, Computers in Human Behavior, 23: 2095-2112.

Zohar, A. (1999). Teachers, meta cognitive knowledge and the instruction of higher order thinking. Teaching and Teacher Education, 15, pp. 413-429. 